\title{
Parental Origin of de novo \\ Cytogenetically Balanced Reciprocal Non-Robertsonian Translocations
}

\author{
M. Höcknera A. Spreiz ${ }^{a} \quad$ A. Frühmesser ${ }^{a} \quad$ A. Tzschach ${ }^{c, d}$ A. Dufke ${ }^{d}$ \\ O. Rittinger ${ }^{b} \quad$ V. Kalscheuer ${ }^{c} \quad$ S. Singer ${ }^{d} \quad$ M. Erdel ${ }^{a} \quad$ C. Fauth ${ }^{a} \quad$ V. Grossmann ${ }^{a}$ \\ G. Utermann ${ }^{\mathrm{a}} \quad$ J.Zschocke ${ }^{\mathrm{a}} \quad$ D. Kotzot ${ }^{\mathrm{a}}$ \\ a Division of Human Genetics, Department of Medical Genetics, Molecular and Clinical Pharmacology, Innsbruck \\ Medical University, Innsbruck, and b ${ }^{b}$ ection Clinical Genetics, Department of Pediatrics, Paracelsus Medical \\ University Salzburg, Salzburg, Austria; ' Department of Human Molecular Genetics, Max Planck Institute for \\ Molecular Genetics, Berlin, and d Department of Medical Genetics, University of Tübingen, Tübingen, Germany
}

\section{Key Words}

Meiosis $\cdot$ Mitosis $\cdot$ Parental origin $\cdot$ Translocation

\section{Abstract}

De novo cytogenetically balanced reciprocal non-Robertsonian translocations are rare findings in clinical cytogenetics and might be associated with an abnormal phenotype. Knowledge of the parental origin and mechanisms of formation is still limited. By microdissection of the derivative chromosomes and their normal homologs from metaphases followed by microsatellite-mediated marker analysis we identified 7 cases of paternal and 3 cases of maternal origin in a cohort of 10 patients with de novo cytogenetically balanced reciprocal non-Robertsonian translocations. Neither in the maternal nor in the paternal group of our study parental age seems to be increased. Together with the data from the literature our results confirm that the majority of de novo cytogenetically balanced reciprocal translocations are of paternal origin, but the preponderance does not appear to be as distinct as previously thought and the paternal age does not seem to be necessarily a major contributing factor.

\section{KARGER}

Fax +4161306 1234

E-Mail karger@karger.ch

www.karger.com
(C) 2012 S. Karger AG, Basel

$1424-8581 / 12 / 1364-0242 \$ 38.00 / 0$

Accessible online at:

www.karger.com/cgr
Balanced reciprocal non-Robertsonian translocations detected by conventional karyotyping are found in about 1:1,000 newborns [Gardner and Sutherland, 2003]. In most of these cases one of the parents carries the same translocation. In contrast, de novo balanced reciprocal non-Robertsonian translocations are rare, but their investigation might help to improve our understanding of the parental origin and formation of constitutional chromosomal rearrangements.

Here, we report on the preferentially paternal origin in a cohort of 10 patients with de novo balanced reciprocal non-Robertsonian translocations.

\section{Methods}

Conventional karyotyping (GTG banding) of lymphocytes was performed in 10 patients ( 6 females and 4 males) and their parents according to standard protocols. A minimum of 20 metaphases was evaluated in each proband. Minimum banding

M.H. and A.S. contributed equally to this work.
Dieter Kotzot, Division of Human Genetics

Department of Medical Genetics, Molecular and Clinical Pharmacology Innsbruck Medical University, Schoepfstr. 41

AT-6020 Innsbruck (Austria)

Tel. +435129003 70543, E-Mail DieterKotzot@gmx.de 
Table 1. Results of molecular marker investigation subsequent to whole genome amplification of microdissected chromosomes in 10 patients with de novo cytogenetically balanced non-Robertsonian translocations

\begin{tabular}{|c|c|c|c|c|c|c|c|c|}
\hline $\begin{array}{l}\text { Pro- } \\
\text { band } \\
\text { No. }\end{array}$ & Karyotype & Marker & M & $\mathrm{P}$ & $\mathrm{F}$ & $\begin{array}{l}\text { Microdissected } \\
\text { chromosome }\end{array}$ & $\begin{array}{l}\text { Parental } \\
\text { origin }\end{array}$ & Congenital anomalies \\
\hline 1 & $46, \mathrm{XX}, \mathrm{t}(2 ; 3)(\mathrm{q} 33 ; \mathrm{q} 23)$ & $\begin{array}{l}\text { D2S2297 } \\
\text { D2S2297 }\end{array}$ & $\begin{array}{l}\mathrm{AB} \\
\mathrm{AB}\end{array}$ & $\begin{array}{l}\mathrm{AB} \\
\mathrm{AB}\end{array}$ & $\begin{array}{l}\text { AA } \\
\text { AA }\end{array}$ & $\begin{array}{l}\mathrm{h}(2) \rightarrow \mathrm{A} \\
\operatorname{der}(3) \rightarrow \mathrm{A}\end{array}$ & paternal & + [Tzschach et al., 2008] \\
\hline 2 & $46, \mathrm{XX}, \mathrm{t}(2 ; 5)(\mathrm{p} 21 ; \mathrm{q} 11.2)$ & $\begin{array}{l}\text { D2S2387 } \\
\text { D2S115 } \\
\text { D5S659 }\end{array}$ & $\begin{array}{l}\mathrm{BD} \\
\mathrm{BD} \\
\mathrm{BB}\end{array}$ & $\begin{array}{l}\mathrm{CD} \\
\mathrm{AD} \\
\mathrm{AB}\end{array}$ & $\begin{array}{l}\text { AC } \\
\text { AC } \\
\text { AA }\end{array}$ & $\begin{array}{l}\operatorname{der}(2) \rightarrow C \\
\operatorname{der}(2) \rightarrow A \\
h(5) \rightarrow B\end{array}$ & paternal & $+[$ Tzschach et al., 2010] \\
\hline 3 & $46, \mathrm{XX}, \mathrm{t}(2 ; 7)(\mathrm{q} 23 ; \mathrm{p} 21)$ & $\begin{array}{l}\text { D2S2387 } \\
\text { D2S309 } \\
\text { D7S500 }\end{array}$ & $\begin{array}{l}\mathrm{BB} \\
\mathrm{BC} \\
\mathrm{AD}\end{array}$ & $\begin{array}{l}\mathrm{AB} \\
\mathrm{AB} \\
\mathrm{CD}\end{array}$ & $\begin{array}{l}\mathrm{AB} \\
\mathrm{AD} \\
\mathrm{BC}\end{array}$ & $\begin{array}{l}\mathrm{h}(2) \rightarrow \mathrm{B} \\
\operatorname{der}(7) \rightarrow \mathrm{A} \\
\operatorname{der}(7) \rightarrow \mathrm{C}\end{array}$ & paternal & $\begin{array}{l}\text { Intellectual disability, no speech, muscular } \\
\text { hypotonia, myoclonic seizures, no } \\
\text { malformations and no dysmorphisms }\end{array}$ \\
\hline 4 & $46, \mathrm{XX}, \mathrm{t}(2 ; 8)(\mathrm{p} 13 \sim \mathrm{p} 15 ; \mathrm{q} 22)$ & $\begin{array}{l}\text { D2S1788 } \\
\text { D8S554 }\end{array}$ & $\begin{array}{l}\mathrm{AB} \\
\mathrm{AB}\end{array}$ & $\begin{array}{l}\mathrm{AB} \\
\mathrm{AB}\end{array}$ & $\begin{array}{l}\mathrm{AA} \\
\mathrm{BB}\end{array}$ & $\begin{array}{l}\mathrm{h}(2) \rightarrow \mathrm{A} \\
\mathrm{h}(8) \rightarrow \mathrm{B}\end{array}$ & maternal & $\begin{array}{l}\text { Intellectual disability, ataxia, postnatal growth } \\
\text { retardation, seizures, dysmorphisms (narrow } \\
\text { forehead, strabismus, broad nasal bridge, } \\
\text { tapering fingers with fetal pads, sandal gap) }\end{array}$ \\
\hline 5 & $46, \mathrm{XX}, \mathrm{t}(2 ; 13)(\mathrm{p} 13 ; \mathrm{q} 12)$ & $\begin{array}{l}\text { D2S309 } \\
\text { D13S795 } \\
\text { D13S260 }\end{array}$ & $\begin{array}{l}\mathrm{BB} \\
\mathrm{BB} \\
\mathrm{AA}\end{array}$ & $\begin{array}{l}\mathrm{AB} \\
\mathrm{AB} \\
\mathrm{AB}\end{array}$ & $\begin{array}{l}\text { AA } \\
\text { AA } \\
\text { BB }\end{array}$ & $\begin{array}{l}\mathrm{h}(2) \rightarrow \mathrm{B} \\
\mathrm{h}(13) \rightarrow \mathrm{B} \\
\operatorname{der}(13) \rightarrow \mathrm{B}\end{array}$ & paternal & Intellectual disabilty \\
\hline 6 & 46,XY,t(4;5)(q21.1;p15.33) & $\begin{array}{l}\text { D4S424 } \\
\text { D5S2005 }\end{array}$ & $\begin{array}{l}\mathrm{BB} \\
\mathrm{AB}\end{array}$ & $\begin{array}{l}\mathrm{AB} \\
\mathrm{AB}\end{array}$ & $\begin{array}{l}\mathrm{AB} \\
\mathrm{BB}\end{array}$ & $\begin{array}{l}\mathrm{h}(4) \rightarrow \mathrm{A} \\
\mathrm{h}(5) \rightarrow \mathrm{B}\end{array}$ & maternal & Severe intellectual disability, nystagmus \\
\hline 7 & $46, \mathrm{XY}, \mathrm{t}(7 ; 11)(\mathrm{q} 11.21 ; \mathrm{p} 11.2)$ & $\begin{array}{l}\text { D7S2474 } \\
\text { D7S2474 } \\
\text { D7S2426 }\end{array}$ & $\begin{array}{l}\mathrm{AB} \\
\mathrm{AB} \\
\mathrm{AC}\end{array}$ & $\begin{array}{l}\mathrm{AC} \\
\mathrm{AC} \\
\mathrm{AC}\end{array}$ & $\begin{array}{l}\mathrm{CC} \\
\mathrm{CC} \\
\mathrm{AB}\end{array}$ & $\begin{array}{l}\mathrm{h}(7) \rightarrow \mathrm{A} \\
\operatorname{der}(7) \rightarrow \mathrm{C} \\
\operatorname{der}(11) \rightarrow \mathrm{A}\end{array}$ & paternal & + (patient 3 in Kalscheuer et al. [2007]) \\
\hline 8 & $46, \mathrm{XX}, \mathrm{t}(2 ; 4)(\mathrm{p} 16 ; \mathrm{q} 35)$ & $\begin{array}{l}\mathrm{D} 2 \mathrm{~S} 1384 \\
\mathrm{D} 2 \mathrm{~S} 2358 \\
\mathrm{D} 4 \mathrm{~S} 2964\end{array}$ & $\begin{array}{l}\mathrm{BC} \\
\mathrm{CD} \\
\mathrm{BB}\end{array}$ & $\begin{array}{l}\mathrm{AB} \\
\mathrm{BC} \\
\mathrm{AB}\end{array}$ & $\begin{array}{l}\mathrm{AA} \\
\mathrm{AB} \\
\mathrm{AB}\end{array}$ & $\begin{array}{l}\mathrm{h}(2) \rightarrow \mathrm{B} \\
\mathrm{h}(2) \rightarrow \mathrm{C} \\
\operatorname{der}(4) \rightarrow \mathrm{A}\end{array}$ & paternal & - \\
\hline 9 & $46, \mathrm{XY}, \mathrm{t}(6 ; 14)(\mathrm{q} 15 ; \mathrm{q} 24)$ & $\begin{array}{l}\text { D6S310 } \\
\text { D14S1426 }\end{array}$ & $\begin{array}{l}\mathrm{BC} \\
\mathrm{CD}\end{array}$ & $\begin{array}{l}\mathrm{AB} \\
\mathrm{BD}\end{array}$ & $\begin{array}{l}\mathrm{AB} \\
\mathrm{AB}\end{array}$ & $\begin{array}{l}\operatorname{der}(6) \rightarrow \mathrm{A} \\
\operatorname{der}(14) \rightarrow \mathrm{B}\end{array}$ & paternal & - \\
\hline 10 & $46, \mathrm{XY}, \mathrm{t}(18 ; 19)(\mathrm{q} 12.2 ; \mathrm{q} 13.1)$ & D18S61 & $\mathrm{AC}$ & $\mathrm{AB}$ & $\mathrm{BC}$ & $\operatorname{der}(19) \rightarrow \mathrm{A}$ & maternal & - \\
\hline
\end{tabular}

A, B, C, D: different alleles. $\mathrm{F}=$ Father; $\mathrm{M}=$ mother; $\mathrm{P}=$ patient; $\mathrm{h}=$ normal homolog.

level was 500 bands per haplotype. Various congenital anomalies and/or mental retardation were present in 7 patients. The cases of 3 of them (patients 1,2, and 7) were already published elsewhere [Kalscheuer et al., 2007; Tzschach et al., 2008, 2010]. In patients 3, 4, and 9, high-resolution single nucleotide polymorphism- or comparative genomic hybridization-array (Illumina ${ }^{\circledR}$ lM Human 1 M Duo V1 single nucleotide polymorphismarray and Agilent 244k comparative genomic hybridization-array) were performed, both according to the manufacturers' instructions. A resolution of at least $100 \mathrm{~kb}$ was achieved with both types of arrays.

Molecular investigations for the determination of the parental origin were performed by glass needle microdissection of a minimum of 10 copies of the derivative chromosomes and, separately, their normal homologs from metaphases. Afterwards, these chromosomes were analyzed by whole genome amplification with the GenomePlex ${ }^{\circledR}$ single-cell whole genome amplification kit (SigmaAldrich, Vienna, Austria), conventional microsatellite marker polymerase chain reaction, electrophoresis on a $6 \%$ polyacryl- amide gel, and visualized by silver staining according to a protocol recently published by Höckner et al. [2009]. Genotypes of microdissected chromosomes from the probands were compared with genotypes obtained from genomic DNA of the probands and their parents.

\section{Results}

In 3 patients (patients 3, 4, and 9), no deletion or duplication around the breakpoints was found by high-resolution array analyses. As no (possibly causal) deletions/ duplications were found in the patients, the parents were not investigated by array. Other genetic (e.g. smaller deletion/duplication, gene interruption) or exogenous factors could not be excluded. In total, in 7 cases paternal origin and in 3 cases maternal origin was found (table 1, fig. 1). 


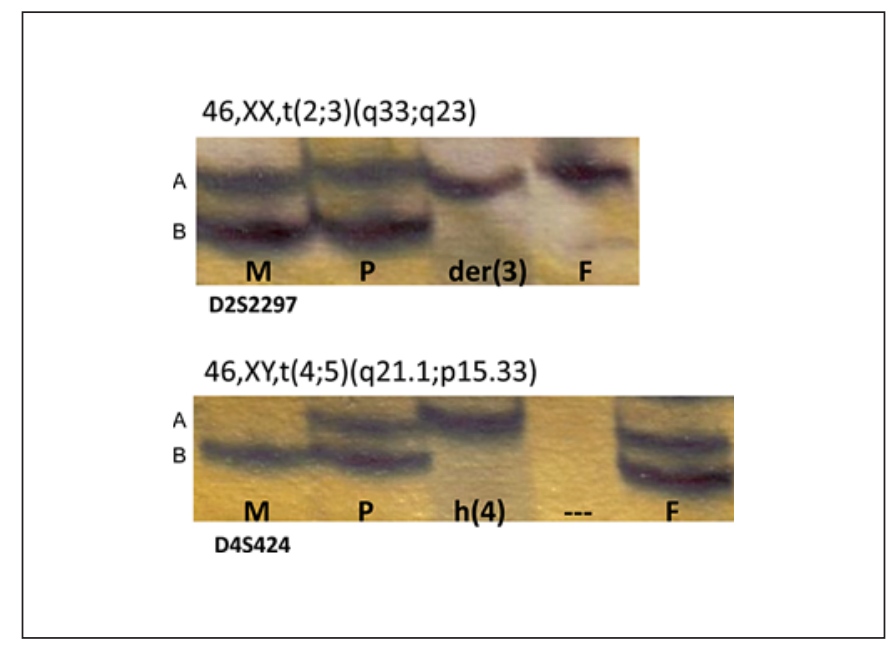

Fig. 1. Molecular results of patient $1(46, \mathrm{XX}, \mathrm{t}(2 ; 3)(\mathrm{q} 33 ; \mathrm{q} 23))$ and patient $6(46, \mathrm{XY}, \mathrm{t}(4 ; 5)(\mathrm{q} 21.1 ; \mathrm{p} 15.33))$ with de novo cytogenetically balanced non-Robertsonian translocation $(\mathrm{M}, \mathrm{P}$, and $\mathrm{F}$ from genomic DNA, der(3) and h(4) from microdissected, whole genome amplified chromosomes). In patient 1 paternal origin of the $\operatorname{der}(3)$ and in patient 6 paternal origin of the $\mathrm{h}(4)$ is shown. $\mathrm{A}=$ Allele $\mathrm{A} ; \mathrm{B}=$ allele $\mathrm{B}$; der = derivative chromosome; $\mathrm{F}=$ father; $\mathrm{h}=$ normal homolog; $\mathrm{M}=$ mother; $\mathrm{P}=$ patient.

Mean maternal age was 26.7 years $(n=7)$ and mean paternal age was 28.7 years $(n=7)$ for paternally originating translocations, while mean maternal and paternal ages were $33(n=3)$ and 36 years $(n=3)$, respectively, for maternally originating translocations. Because of the small number of patients comparative statistical analysis with patients from the literature was not performed.

\section{Discussion}

So far, the knowledge of the parental origin and mechanisms of formation of de novo reciprocal translocations in humans is limited. Due to mutagenesis studies in Drosophila and mice, it has been postulated that structural chromosomal aberrations arise more often in spermatogenesis, whereas numerical chromosomal aberrations are more often of maternal origin [reviewed in Chandley, 1991]. In humans, the former has been documented for the more frequent microdeletions [Thomas et al., 2006] and the latter for the common trisomies 13, 18, and 21 [reviewed in Gardner and Sutherland, 2003].

Robertsonian translocations are the most frequent balanced translocations in humans. Most de novo Robertsonian translocations arise during oogenesis and have breakpoints within a consistent region [Bandyopadhyay et al., 2002]. De novo formation in paternal meiosis of the 11/22 translocation, which is the most common balanced non-Robertsonian reciprocal translocation in man, was deduced from analysis of few cases and also particularly from detection in sperm of men who were not carriers of this translocation. A mechanism of non-homologous end joining of palindromic AT-rich repeats on 11q23 and 22q11 was assumed [Ohye et al., 2010].

So far, in only 2 studies the parental origin of de novo balanced reciprocal translocations was investigated systematically. De Gregori et al. [2007] found paternal origin in 5 de novo reciprocal and 11 de novo complex chromosomal rearrangements, all associated with an abnormal phenotype. By linkage analysis subsequent to flow sorting of the derivative chromosomes Thomas et al. [2010] investigated 27 patients with de novo reciprocal translocations. In only one of them the origin was maternal. Twenty-one of them were associated with an abnormal phenotype. Furthermore, Grossmann et al. [2010] found exclusively paternal origin in 5 de novo balanced complex chromosomal rearrangements.

The occurrence of chromosomal rearrangements is linked to complex features of the genomic architecture, with predisposing DNA structures like palind romic ATrich repeats, pericentromeric repeats, low-copy repeats, and sometimes repetitive sequences. These DNA structures predispose to non-allelic homologous recombination, non-homologous end joining, and fork stalling and template switching, which are considered to be the major mechanisms of formation of recurrent and nonrecurrent structural rearrangements, respectively. Although all these mechanisms are considered to occur with equal frequency in male and female meiosis, postnatally observed frequencies are different. Thomas et al. [2010] suggested that this might be the consequence of the higher number of premeiotic cell divisions in older men. Confirmation would be possible by linkage with grandparental haplotypes. If formed premeiotically, the translocation chromosomes should be a mix of grandpaternal and grandmaternal chromosomes in at least some cases. Unfortunately, most of the grandparents of our probands were already deceased, and therefore these analyses were not possible. The fact that paternal age was significantly increased in the cohort reported by Thomas et al. [2010] $(n=23$; $p<0.008)$ but apparently not in our cohort may be due to the smaller number of patients in our study. 
In summary, our data in combination with the data of the literature confirm that (a) the majority of de novo cytogenetically balanced reciprocal translocations are of paternal origin, and that (b) the preponderance and the paternal age effect do not appear to be as obvious as previously thought.

\section{Acknowledgments}

The authors thank the families for their excellent cooperation and Dr. Rost (Munich), Dr. Demuth (Erfurt), and Dr. Wiedersberg (Schwerin) for referring the patients. This work was supported by grants of the Österreichische Nationalbank to M.E. (No. 12530) and to D.K. (No. 13004).

\section{References}

Bandyopadhyay R, Heller A, Knox-DuBois C, McCaskill C, Berend SA, et al: Parental origin and timing of de novo Robertsonian translocation formation. Am J Hum Genet 71:1456-1462 (2002).

Chandley AC: On the parental origin of de novo mutation in man. J Med Genet 28:217-223 (1991).

-De Gregori M, Ciccone R, Magini P, Pramparo T, Gimelli S, et al: Cryptic deletions are a common finding in 'balanced' reciprocal and complex chromosome rearrangements: a study of 59 patients. J Med Genet 44:750762 (2007).

Gardner RJ, Sutherland GR: Chromosome Abnormalities and Genetic Counseling (Oxford University Press, New York 2003).
Grossmann V, Höckner M, Karmous-Benailly $\mathrm{H}$, Liang D, Puttinger R, et al: Parental origin and possible mechanisms of formation of de novo complex chromosomal rearrangements. Clin Genet 78:548-553 (2010).

Höckner M, Erdel M, Spreiz A, Utermann G, Kotzot D: Whole genome amplification from microdissected chromosomes. Cytogenet Genome Res 125:98-102 (2009).

Kalscheuer VM, FitzPatrick D, Tommerup N, Bugge M, Niebuhr E, et al: Mutations in autism susceptibility candidate 2 (AUTS2) in patients with mental retardation. Hum Genet 121:501-509 (2007).

Ohye T, Inagaki H, Kogo H, Tsutsumi M, Kato T, et al: Paternal origin of the de novo constitutional t(11;22)(q23;q11). Eur J Hum Genet 18: 783-787 (2010).

Thomas NS, Durkie M, Potts G, Sandford R, Van Zyl B, et al: Parental and chromosomal origins of microdeletion and duplication syndromes involving 7q11.23, 15q11-q13 and 22q11. Eur J Hum Genet 14:831-837 (2006).
Thomas NS, Morris JK, Baptista J, Ng BL, Crolla JA, Jacobs PA: De novo apparently balanced translocations in man are predominantly paternal in origin and associated with a significant increase in paternal age. J Med Genet 47:112-115 (2010).

Tzschach A, Kelbova C, Weidensee S, Peters H, Ropers HH, et al: Blepharophimosis-ptosisepicanthus inversus syndrome in a girl with chromosome translocation $\mathrm{t}(2 ; 3)(\mathrm{q} 33 ; \mathrm{q} 23)$. Ophthalmic Genet 29:37-40 (2008).

Tzschach A, Menzel C, Erdogan F, Istifli ES, Rieger M, et al: Characterization of an interstitial $4 \mathrm{q} 32$ deletion in a patient with mental retardation and a complex chromosome rearrangement. Am J Med Genet A 152A:10081012 (2010). 